\title{
Implications of Second Language Acquisition Theory for Business English Teaching in Current China
}

\author{
Zhu Wenzhong ${ }^{1} \&$ Wan Muchun ${ }^{2}$ \\ ${ }^{1}$ School of English for International Business and School of Business, Guangdong University of Foreign Studies, \\ Guangzhou 510420, China \\ ${ }^{2}$ School of Foreign Languages, Shenyang Normal University, Shenyang 110011, China \\ Correspondence: Zhu Wenzhong, School of Business MBA Education Center, Guangdong University of Foreign \\ Studies, Guangzhou 510420, China. Tel: 86-20-36204305. E-mail: wenzhong8988@sina.com
}

Received: May 13, 2015 Accepted: July 28, 2015 Online Published: August 12, 2015

doi:10.5539/elt.v8n9p112 URL: http://dx.doi.org/10.5539/elt.v8n9p112

\begin{abstract}
Second language acquisition (SLA) as a sub-branch of applied linguistics has been researched by Chinese and foreign scholars for over 40 years, but few researches have been done on its implications for Business English teaching which needs more language teaching theories to support. This paper makes a review of related studies, and puts forward a systematic framework of exploring the essential implications of second language acquisition theory for Business English teaching in current China based on the SLA concepts of input hypothesis, output hypothesis, affective filter hypothesis, learner-centered approach, natural language context, communicative approach, etc. along the whole process of Business English teaching. It concludes that the theory of SLA is applicable for Business English teaching in China and has essential implications in Business English curriculum design, teaching material selection, teaching method selection, and performance evaluation.
\end{abstract}

Keywords: second language acquisition, Business English teaching, China, implication

\section{Introduction}

Business English is defined as the application of English language in business situations. According to Ellis and Johnson (9994), Business English must be seen in the overall context of ESP as it shares the important elements of needs analysis, syllabus design, course design, and material selection which are common to all varieties of work in ESP, but it differs from other types of ESP in that is often a mix of specific content relating to a particular job area or industry and general content relating to general ability to communicate more effectively in business situations.

As a result of economic globalization, Business English has now evolved from traditional applied linguistics or ESP into a new cross-disciplinary degree programme in China. It is commonly recognized that Business English education will be the trend or direction of English language education in the future, so more and more Chinese universities, especially the application-oriented higher education institutions or vocational technical colleges, are transferring their talent training focus strategy from General English majors to Business English majors. However, so far, the newly-established independent discipline of Business English in China still lacks a theoretical framework of its own, and thus, more researches on Business English teaching theories and methods should be conducted from different applicable theories and practices already existing in the academia.

Second language acquisition is the process by which people learn a second language. That is, it is the process of learning an additional language by someone who has already learned a native language or multiple native languages. It can also refer to the scientific study of the second-language learning process. Second language acquisition refers to what the learner does; it does not refer to what teachers do. Thus, according to the definition, leaner-centered approach is more emphasized than teacher-centered approach.

The study of second language acquisition has started from the late 1960s, but the theory of inter-language proposed by Selinker (1972) makes the very beginning of SLA researches as an independent field of study from applied linguistics. The related study has been widened to cover more and more fields of applied linguistics, social linguistics, psycholinguistics, education studies, etc. In the US, Krashen $(1981,1985)$ puts forward the fundamental pedagogical principle in second language teaching, and his input hypothesis and affective filter 
hypothesis have ever since attracted a lot of attention in the academia. In the past over 30 years, researchers in China have also done a series of studies on the theory of SLA, for example, Gui Shichun and Ning chunyan (1997), Jiang Zukang (1999), Liu Shaolong (2000), Gao Xiang (2001), and others. Various ideas are put forward, but there is a common concept shared by these researchers, which is that: the theory of second language acquisition is applicable and conductive to English language teaching practices, at least to some extent, because there are no absolutely applicable methods of English teaching, and any theory of English language teaching may have its specific limitations in application.

The present research will try to answer the questions such as: How is the theory of SLA applicable for Business English teaching? Or what are the essential implications of SLA theory for Business English teaching in China? This paper makes a detailed review of related studies, and points out the essential implications of second language acquisition theory for Business English teaching in current China, in order to enrich the theoretical foundation of Business English development.

\section{Literature Review}

\subsection{Status Quo of Researches on SLA abroad}

Since the theory of inter-language proposed by Selinker (1972) makes the very beginning of SLA researches as an independent field of study from applied linguistics as mentioned above, the study of SLA in the west has undergone over 40 years. In fact, prior to the 1970s, Chomsky (1965) argues that creation is one of a language's natural features as children can acquire language creatively, and his statement of first language acquisition has actually paved a new theoretical foundation for the study of SLA. Selinker (1972) argues that the language system mastered by second language learners in a specific period or context is an independent language system which is distinctive from both first language and second language, and it is really an inter-language. Inter-language refers to the systematic knowledge of a second language which is independent of both the learner's first language and the target language. Ellis (1994) argues that inter-language is a proper starting point of SLA studies, as it is the first theory used to interpret the theory of SLA, and marks the birth of SLA study as a new independent discipline. Yip and Matthews (1995) argue that inter-language results from the error of analysis since its concern is not just about the language error, but more about the whole system of language knowledge. Gass (2008) argues that SLA should cover all aspects of second language or foreign language teaching studies, such as: which second language elements can acquired, how learners can create new language systems with limited inputs, and how a second language leaner can reach the same level as his or her mother tongue.

\subsection{Status Quo of Researches on SLA in China}

The study of SLA in China starts about a decade later than that in the west. Over the past over 30 years, the study has undergone three main eras. The first era of the study of SLA in China starts from the early 1980s, during which Chinese researchers begin to translate, introduce, review or publishes the basic theory of SLA from the west. For example, Qian (1981) makes an introduction to the communicative language teaching theory of Widdowson as an authority in the field of applied linguistics and language teaching, specifically English language learning and teaching; Gui (1984) as a very famous Chinese linguist and foreign language educationist publishes his book of Psycholinguistics.

The second era begins from the early 1990s, in which scholars' research focuses change from the teaching of teachers to the learning of learners, more aiming to research affective filter factors and learning conditions or contexts and their influences on the acquisition performance of learners, for example, Wang (1991) makes a research on cognitive and emotional needs in foreign language learning practices. The study of this era tends to critically analyze the theory of SLA based on the practical situation of Chinese learners' foreign language learning, rather than simply introducing the second language acquisition theory from the west.

The third era starts from the early 2000s, in which more and more Chinese scholars participate in new areas or fields of SLA study and thus greatly deepen the scope of related researches such as learners' individual differences, learning strategies, cognitive differences, and cultural differences. For instance, $\mathrm{Wu}(2000)$ makes an analysis of cognitive psychology in the process of Second Language Acquisition; Wang (2001) makes a discussion on the problems and countermeasures in the study of second language learning strategies; Feng (2003) makes research on individual learner differences in the successful SLA; Xu (2007) makes a study on the application of second language acquisition and learning strategies in English learning.

\subsection{Status Quo of Researches on SLA and Business English Teaching in China}

Researches on SLA and Business English teaching in China start from about the late 2000s to now. The Chinese scholars and their researches in this field of study are summarized as follows: Xiao (2008) makes an analysis of 
the application of Krashen's SLA theory on Business English Teaching, and explores the problems in the Business English teaching practice of China from the view of Krashen's theory; Chu (2010) makes a study on the Business English writing under the framework of Krashen's SLA theory; Zhang (2014) makes a study on the current situation of Business English writing textbooks based on the theoretical framework of Krashen's second language acquisition theory; Wang (2014) makes an empirical study on college Business English curriculum based on the influential factors of teachers' development student achievement assessment practices from SLA perspective.

As a brief summary, the existing researches on SLA theory have valued the new development of general linguistics, functional grammar, etc., and have widened the areas of study such as social linguistics, psycholinguistics, pragmatics, as well as empirical studies based on theory. That is to say, the theory of SLA is not just a consumer of linguistics, but an important contributor to it. But of course, the existing researches on SLA still lack the direct findings on the successful application of SLA theory in the real English teaching practice, and there are some researchers or teachers directly or blindly copying the idea of SLA theory in their teaching practices without considering the specific learning environment of China and the difference between individual learners, so that they have not reached their expected results.

As for the existing researches on SLA and Business English in China, the number of the researches is still very limited, not saying that these researches on Business English writing, curriculum design teacher development based on SLA theory are in shortage of systematic thinking or key points. This present study, however, will explore the essential implications of second language acquisition theory for Business English teaching in current China based on the SLA-related concepts of input hypothesis, output hypothesis, affective filter hypothesis, learner-centered approach, natural language context, communicative approach, etc. along the whole process of Business English teaching (See Figure 1), which may be more logical, comprehensive and systematic.

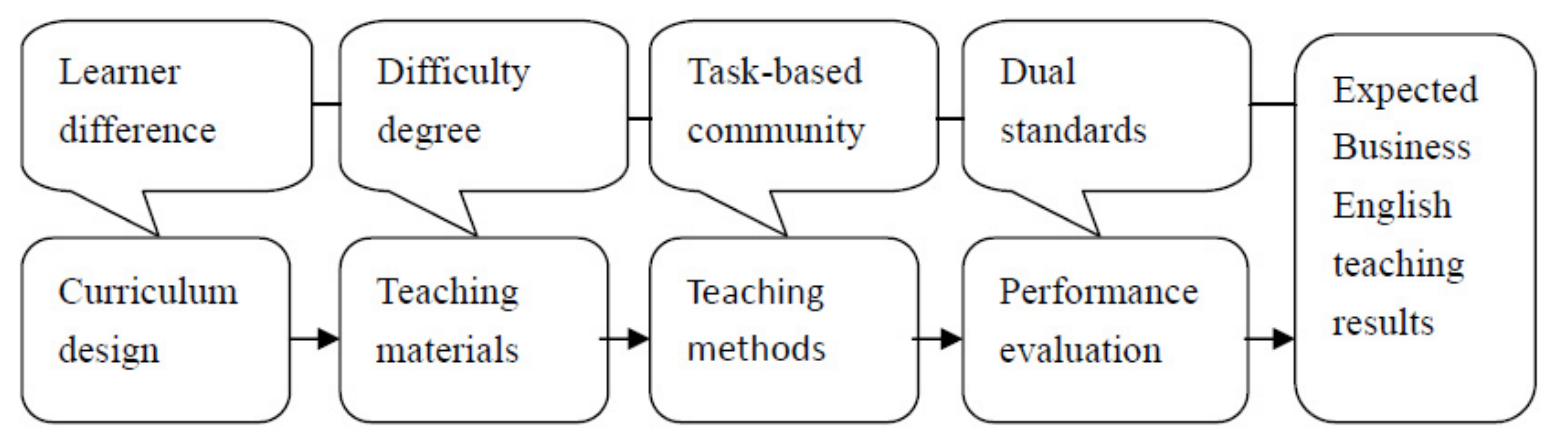

Figure 1. Analysis framework of the present study on essential implications of SLA for business English teaching

\section{Essential Implications}

There are quite a lot of implications of SLA theory for Business English teaching in today's China, but the following are argued by the author to be the essential ones:

\subsection{Business English Curriculum Design}

Based on the development history of SLA theory, one of the conceptual changes to improve the effect of foreign language teaching is from "how to teach" to "how to learn". Thus, the learner-centered approach rather than the teacher-centered approach becomes popular and prosperous with the rise of SLA studies. For the curriculum design of Business English, it is thus important to design the courses to meet the needs of different learners (pre-experienced learners and job-experienced learners).

In China today, Business English is mainly a degree program for pre-experienced college students, but of course, there are also a few training programs for professionals or job-experienced managers in the real business world. Therefore, the curriculum design should differ for pre-experienced learners and job-experienced learners, so the course design for pre-experienced learners as college students should be determined by the departmental leaders and teachers of the university with sufficient consideration of learners' needs, while that for job-experienced learners should be decided through careful discussions with the learners and their organizational managers. In 
addition, to motivate the learners' study attitude, the curriculum design of Business English in Chinese universities should also consider to set up the courses of distinctive local characteristics such as the specific business knowledge and business culture needed by jobs in the leading local industry.

\subsection{Teaching Materials Selection}

Based on the idea of input hypothesis, comprehensible input is the precondition for second language acquisition. According to the concept of affective filter hypothesis, the learners' emotional factors such as attitude, motivation and self-confidence, etc. will filter the input and constrain the effect of input, thus leading to the reduction of effects of second language acquisition. The teaching materials selected for Business English courses should first ensure that the materials designed for Business English to be in a proper degree of difficulty and suitability. If the learners are not able to understand the theories, concepts or terms in the input of business-related materials, they will lose their confidence and motivation for the learning.

Pre-experienced learners will expect to learn about both the theory and practice of business, so the teaching materials for them should provide them more understandable information about the business subjects in question such as business terms, theories and practices. Business inputs such as business terms or key words, business background knowledge, business communication skills, business writing formats, etc. are more necessary and feasible for pre-experienced learners.

The teaching materials for job-experienced learners, however, should be the providing of language input rather than business input. What is equally important is that, the teaching materials designed for the learners of Business English should ensure to be attractive to them, so that they will be motivated to learn better with minimized affective filter effects.

\subsection{Teaching Methods Application}

Based the view of Kranshen (1981), language acquisition can only be achieved in an natural language context (although this argument may have limitations, this is because the instruction of tutors is also important), and referring to the idea of Mangubhai (1991), more practices of language will enable students to achieve higher marks than fewer practices in second language proficiency. In a general sense, it is argued that in the second language teaching practices of reading, listening, writing and speaking, teachers should try best to create a kind simulated business environment for communication or task-based community under the instruction tutors in order to realize second language proficiency. Therefore, in the selection of teaching methods, task-based learning method and communicative approach should be emphasized for Business English teaching. The teachers of Business English teachers should try best to create a classroom environment in which real business communication can take place and can be practiced. The practices learners can get from the class should be tasks which simulate those of the real business situation as closely as possible. These tasks set up by the teacher should have specific clearly-defined objectives at the beginning, which relate to the learner's overall learning objectives in studying the course and to his or her level of ability.

In addition, in the practice of Business English teaching in China, it is suggested that business-knowledge courses and business culture courses should be taught in English or bilingualism, and the tutor should use the original English teaching materials in his or her teaching and instruct the teaching chiefly in English but explain some difficult points partially in Chinese so that learners can understand better and acquire more. This is also in conformity with the concept of comprehensive input proposed by Krashen in 1985. The method of bilingual teaching of Business English courses will bring about more output as a result of comprehensive input to the learner. Furthermore, in modern times, electronic videos of business cases can also be used to facilitate the teaching of Business English courses in order to stimulate the interest of learners and achieve better teaching effect.

\subsection{Performance Evaluation}

Based on the concept of learner-centered approach in SLA and the fact of learner differences, the evaluation of Business English students' performance in second language acquisition should take a kind of dual-standard method. The criteria for learners' learning or acquisition performance should be different based on the different performance requirements for pre-experienced learners (college students) and job-experienced learners (business professionals or managers). The dual standards for them are seen as in Table 1. 
Table 1. Dual standards of Business English learners' learning performance

\begin{tabular}{|c|c|c|}
\hline Type of learners & Learners' needs and focuses & Evaluation standards \\
\hline \multirow[t]{4}{*}{$\begin{array}{l}\text { Pre-experienced } \\
\text { learners }\end{array}$} & $\begin{array}{l}\text { 1. Input of business terms, } \\
\text { business theories and practices }\end{array}$ & $\begin{array}{l}\text { 1. Formal examinations or tests } \\
\text { for module credits and degree } \\
\text { awarding }\end{array}$ \\
\hline & culture & $\begin{array}{l}\text { 2. TEM4 and TEM8 (Test for } \\
\text { English Major) }\end{array}$ \\
\hline & $\begin{array}{l}\text { personal qualities and cross-cultural } \\
\text { business communication ability for }\end{array}$ & $\begin{array}{l}\text { 3. Business English certificate } \\
\text { tests }\end{array}$ \\
\hline & $\begin{array}{l}\text { passing credit courses of graduation } \\
\text { and meeting the need of future jobs }\end{array}$ & $\begin{array}{l}\text { 4. Tests for business-related } \\
\text { professional qualifications }\end{array}$ \\
\hline \multirow{4}{*}{$\begin{array}{l}\text { Job-experienced } \\
\text { learners }\end{array}$} & Input of language & \multirow{2}{*}{$\begin{array}{l}\text { 1. Informal tests for completion } \\
\text { of a training course or the whole } \\
\text { program }\end{array}$} \\
\hline & $\begin{array}{l}2 . \quad \text { Input of background } \\
\text { knowledge or theory of business }\end{array}$ & \\
\hline & $\begin{array}{ll}\text { 3. Improvement of Business } \\
\text { English language proficiency and }\end{array}$ & $\begin{array}{l}\text { 2. Feedback reports to learners' } \\
\text { organizations }\end{array}$ \\
\hline & $\begin{array}{l}\text { cross-cultural business communication } \\
\text { ability for better career development }\end{array}$ & $\begin{array}{l}\text { 3. Face-to-face discussion with } \\
\text { the learners based on the attainment } \\
\text { contract }\end{array}$ \\
\hline
\end{tabular}

From the above table, we can see that pre-experienced Business English learners have the needs for and focuses on the input of business terms, theories, language and culture as well as the improvement of comprehensive personal qualities and cross-cultural business communication ability, and what is important is to pass their credit modules and to be awarded degree certificates, so the first standard of evaluation is the passing of the required formal tests for modules and the required TEM4 or TEM8 tests for English major proficiency, and at the same, they can be selectively evaluated by passing Business English certificate tests and other tests for business-related professional qualifications so that they will be more competitive in the labor market.

Job-experienced learners, however, as a result of their major needs and focuses are placed on the input of language, background business knowledge and theory, as well as the improvement of Business English language proficiency and cross-cultural business communication ability for better career development, so the attainment evaluation standards are mostly informal tests, and trainer' feedbacks based on the agreement between the trainer and the trainee. Therefore, it is more rational to develop a dual standard of performance evaluation for pre-experienced learners and job-experienced learners of Business English.

\section{Conclusion}

This paper makes a detailed review of related studies, puts forward a systematic framework of exploring the essential implications of second language acquisition theory for Business English teaching in current China mainly based on the SLA-related concepts of input hypothesis, output hypothesis, affective filter hypothesis, learner-centered approach, natural language context, communicative approach, etc. along the whole process of Business English teaching. It concludes that the theory of SLA is applicable for Business English teaching in China and the essential implications can be seen as following:

First, based on the learner-centered approach, for the curriculum design of Business English, it is important to design the courses to meet the needs of different learners and reflect local distinctive local characteristics. Second, based on the idea of input hypothesis, comprehensible input and affective filter hypothesis, the teaching materials selected for Business English courses should first ensure that the materials designed for Business English to be in a proper degree of difficulty and suitability. Third, in the selection of teaching methods, task-based learning method and communicative approach should be emphasized for Business English teaching, so as to create a classroom environment in which real business communication can take place and can be practiced. Finally, based on the concept of learner-centered approach in SLA and the fact of learner differences, the evaluation of Business English students' performance in second language acquisition should take a kind of dual-standard method, namely the criteria for their learning or acquisition performance should be different based on the different performance requirements for pre-experienced learners and job-experienced learners. 


\section{Acknowledgements}

This paper is supported by the Innovative School Project in Higher Education of Guangdong, China (GWTP-LH-2014-01) and the 2012 Project of Higher Education Teaching Quality and Reform (222-GK120063) sponsored by Guangdong Provincial Department of Education.

\section{References}

Chomsky, A. N. (1965). Aspects of a Theory of Syntax. Cambridge. Mass. MIT Press.

Chu, H. Y. (2010). Business English writing under the framework of Krashen's SLA theory. Journal of China Adult Education.

Ellis, M., \& Johnson, C. (1994). Teaching Business English. Oxford University Press.

Ellis, R. (1994). Understanding second language acquisition. Oxford University Press.

Feng, W. L. (2003). Individual Learner Differences in the Successful SLA. Journal of Wuxi South Ocean College.

Gao, X. (2001). The Theory of Second Language Acquisition and its Enlightenments to our Country's Foreign Languages Teaching. Journal of Xi'an Foreign Languages University.

Gass, S. (2009). Selected Works of Susan Gass on Applied Linguistics. Beijing: Foreign Language Teaching and Research Press.

Gui, S. C., \& Ning, C. Y. (1997). Methodology of Linguistics. Foreign Language Teaching and Research Press.

Gui, S. C. (1984). Psycholinguistics. Shanghai Foreign Languages Education Press.

Jiang, Z. C. (1999). Research on Second Language Acquisition. Foreign Language Teaching and Research Press.

Krashen, S. (1981). The fundamental pedagogical principle in second language teaching. Studia Linguistica. http://dx.doi.org/10.1111/j.1467-9582.1981.tb00701.x

Krashen, S. (1985).The Input Hypothesis: Issues and Applications. London: Longman.

Liu, S. L. L. (2000). Acquisition and its Logical Problem. Journal of PLA Foreign Languages University.

Mangubhai, F. (1991). The processing behaviors of adult second language learners and their relationship to second language proficiency. Applied Linguistics. http://dx.doi.org/10.1093/applin/12.3.268

Qian, Z. M. (1981). Context and Semanteme. Journal of Foreign Language Teaching and Research.

Selinker, L. (1972). Interlanguage, IRAL. International Review of Applied Linguistics in Language Teaching. http://dx.doi.org/10.1515/iral.1972.10.1-4.209

Wang, C. M. (1991). Cognitive and Emotional Needs in Foreign language Learning. Journal of Foreign Language Teaching and Research.

Wu, Q. L. (2000). Analysis of Cognitive Psychology in the Process of Second Language Acquisition. Journal of Foreign Language Teaching and Research.

Wang, L. F. (2001). Problems and Countermeasures in the Study of Second Language Learning Strategies. Journal of Foreign Languages Teaching.

Wang, Y. Y. (2014). The influential factors of teachers' development student achievement assessment practices from second language acquisition perspective -an empirical study on college Business English curriculum. Journal of Guangdong University of Foreign Studies.

Xu, J. G. (2007). The application of second language acquisition and learning strategies in English learning. Journal of Guizhou University (Social Sciences).

Xiao, Z. F. (2008). Analysis of the application of Krashen's SLA theory on Business English Teaching. Journal of Science and Technology Information.

Yip, V., \& Matthews, S. (1995). I-Interlanguage and typology. In L. Eubank (Ed.), The Current State of Interlanguage. Amsterdam: John Benjamins. http://dx.doi.org/10.1075/z.73.03yip

Zhang, F. H. (2014). A study on the current situation of Business English writing textbooks based on the theoretical framework of Krashen's second language acquisition theory. Journal of Hebei United University (Social Sciences Edition). 


\section{Copyrights}

Copyright for this article is retained by the author(s), with first publication rights granted to the journal.

This is an open-access article distributed under the terms and conditions of the Creative Commons Attribution license (http://creativecommons.org/licenses/by/3.0/). 